\title{
Dansk bladtegning og nazismen
}

I efteräret 2012 udstillede Museet for Dansk Bladtegning en lang rakke tegninger fra tiden for, under og efter den tyske besattelse af Danmark 1940-1945.

Udstillingen er blevet fastholdt i bogform, og dens ene redaktor fortaller her om tilblivelsen af udstillingen og udvalgelsen blandt de mange unikke bladtegninger, som bibliotekets samlinger rummer.

afprojektmedarbejder, cand.mag. Hannibal Munk, Museet for Dansk Bladtegning, Det Kongelige Bibliotek

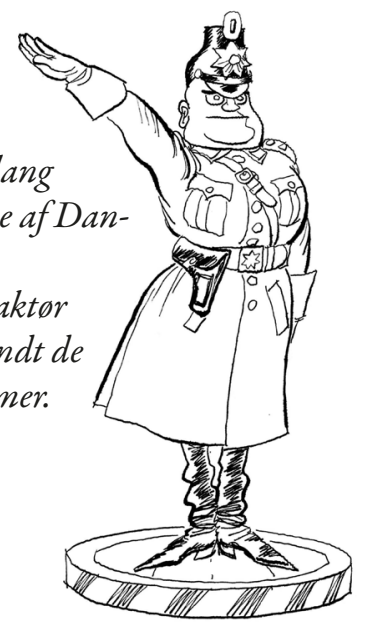

$\mathrm{M}$ useet for Dansk Bladtegning på Det Kongelige Bibliotek fik i forbindelse med udgivelsen af forskningschef John T. Lauridsens store samling af Werner Bests korrespondance i efteråret 2012 stillet til opgave at skabe en udstilling om dansk bladtegnings fremstilling af den nazistiske ideologi og dens hovedpersoner. Det skulle ende med at blive en udstilling med stor publikumssucces, idet emnet var ganske godt egnet til en fremvisning - mange forbipasserende på Kirkebybroen i Den Sorte Diamant fandt det spændende at se både den anonyme, tyske soldat og Hitler blive fremstillet satirisk. Følgende er en gennemgang af de overvejelser, udstillingens redaktører, museets daglige leder, Claus Seidel og undertegnede gjorde sig før, under og efter udstillingens tilblivelse. Det er også historien om en interessant opdagelse, vi gjorde undervejs.

Da museet fik stillet opgaven at skildre det nazistiske uvæsen i en større udstilling med tegninger fra før, under og efter besættelsen, var det første, vi gjorde, at finde de mange tegninger som dels havde været kendt i samtiden, fordi de havde skabt opmærksomhed omkring sig og deres ophavsmænd - hvilket vi vil vende tilbage til - dels dem eftertiden havde gjort kendt ved at gengive i diverse opsamlingsværker. Men for også at finde og udstille tegninger, der ikke nødvendigvis var blevet vist for eftertiden tidligere, dykkede vi ned i de større aviser i udvalgte måneder og år. Dette var især nyttigt for tiden før krigen - dvs. i løbet af 1930'rne. Samlet set gav det os et bredt udvalg af tegninger fra tiden op til anden verdenskrig, dels fra dagspressen, dels fra de satiriske julehæfter som Bleksprutten og Svikmøllen og dels fra de kulturradikale blade, som prægede tiden, netop fordi de var en reaktion mod de totalitære bevægelser i Europa. Af disse sidste kan nævnes de vigtigste: Aandebullet fra 1933-1935 og Kulturkampen fra 1936-1939. Hele vejen hen over det brede, pressepolitiske spektrum var aviserne repræsenteret fra Socialdemokraten og Ekstra Bladet på midt-venstre fløjen til de borgerlige Berlingske Tidende og Dagens Nyheder/ Nationaltidende. Den eneste avis, der ikke var repræsenteret, var Politiken - avisen, der allerede dengang betragtede sig selv 


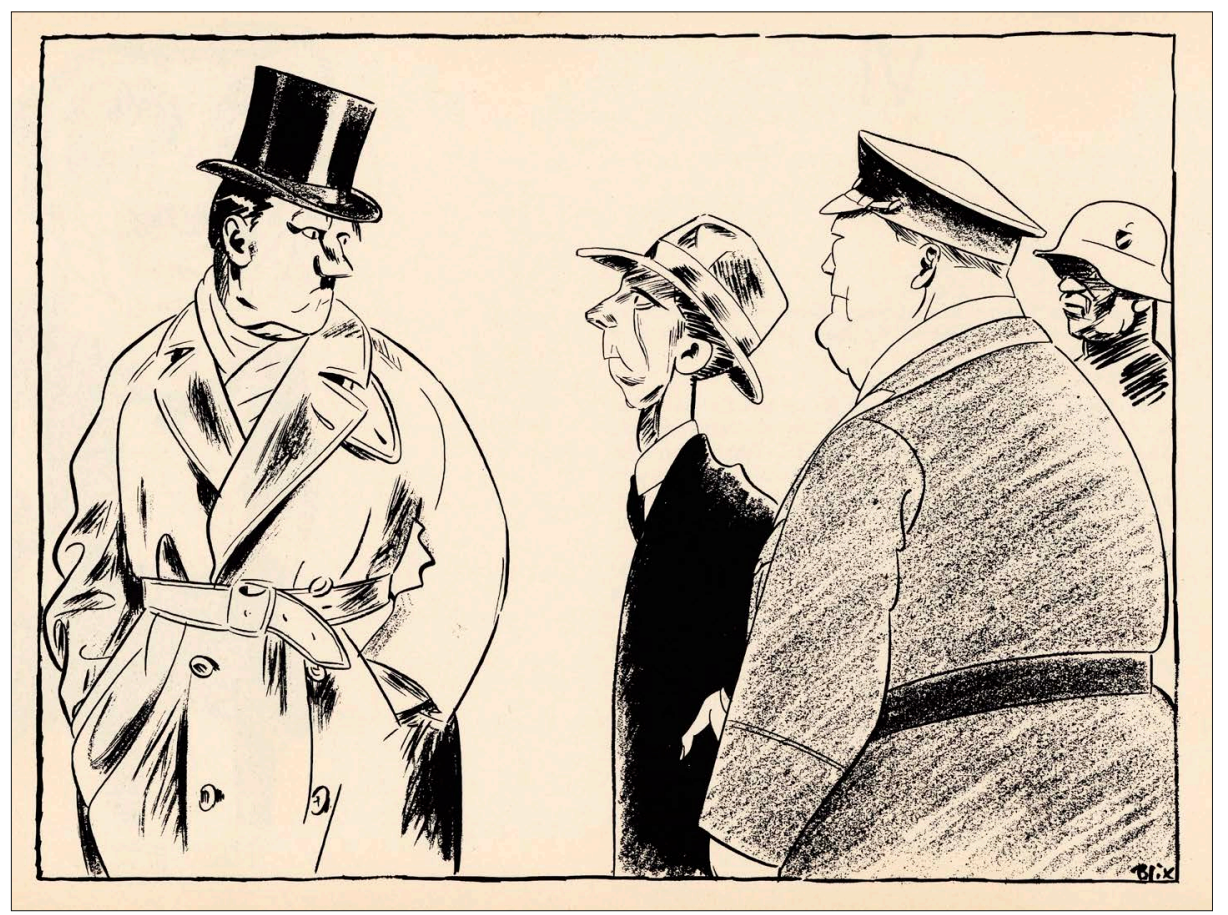

Østrigs Nazificering

- Men tør vi kaste Folk i Fangsel fordi de er gemytlige?

Østrigernes Sorgløshed er antinational. Ragnvald Blix i Berlingske Tidende d. 30. april 1933

som "bladtegnernes egen avis". Vi undrede os såre over dette, men gjorde i første omgang ikke yderligere krumspring for at presse noget ind, der måske ikke fandtes. Vi stod jo med mesterværker fra Socialdemokratens triumvirat af bidske og dygtige tegnere: Levemanden Hans Bendix, den senere kommunist Herluf Bidstrup og den store, sociale tegner Anton Hansen. Med Dagens Nybeders og senere Berlingske Tidendes joviale satiriker Herluf Jensenius samt den exceptionelt skarpe nordmand - ansat af Berlingske Tidende og bosat på Østerbro - Ragnvald Blix. Vi fandt også mere ukendte, men ikke meget mindre illustrative bidragsydere som Ekstra Bladets
Niels Spott (kunstnernavn for en vis Arvid Møller) og Berlingske Tidendes Christian Hoff, der begge næsten er gået i glemmebogen, men som var respekteret i deres samtid. ${ }^{1}$ Sluttelig havde vi enkelte bidrag fra tegnere, der sjældnere var at finde i den satiriske genre som Arne Ungermann og Ib Andersen - manden, der efter krigen tegnede motiverne på de danske pengesedler. Alt i alt kunne vi præsentere en bred vifte af tegnere, bestående af både de stærke satirikere og dem, der normalt ikke beskæftigede sig med emnet. Det var med til at vise præcist, hvor stort og unormalt et væsen nazismen var, at alle gav deres besyv med for ved hjælp af satiren at kritisere den. 
$\mathrm{T}$ dligere i 2012 havde Rigsarkivet lavet udstillingen "Bundet på mund og hånd" om pressecensur før og under krigen. Heri havde de fremvist et dokument - et referat fra et møde på udenrigsminister $\mathrm{P}$. Munchs kontor mellem ham og de danske chefredaktører afholdt den 2. marts 1933, dvs. en måned efter Hitlers magtovertagelse. Referatet nævner, at P. Munch advarede chefredaktørerne mod det nye styre hos naboen mod syd, og han frarådede dem at kommentere udenlandske statsledere $i$ to af deres virkemidler: Overskrifterne og tegningerne. Dem skulle man passe på med. På det tidspunkt var der god grund til at underrette redaktørerne om denne politiske holdning fra regeringens side: En blanding af den store, danske opmærksomhed på den tyske udvikling efter første verdenskrig og den store opblomstring $\mathrm{i}$ dansk bladtegning - også i et internationalt perspektiv, f.eks. med Anton Hansens samarbejde med det tyske satireblad Simplicissimus - havde allerede tidligt resulteret i mange, satiriske tegninger af Adolf Hitler og hans nazistiske parti - også før magtovertagelsen 30. januar 1933.

Således var udstillingens tidligste bidrag en skarp og historisk bevidst tegning udført af Anton Hansen forestillende Hitler stående ved en kirkegård, heilende, samtidig med at de tyske krigere fra første verdenskrig rejser sig fra deres grave for endnu en gang at tjene deres land. Tegningernes antal steg, og deres bid intensiveredes efter valget i den første måned af 1933 i både Socialdemokraten, Ekstra Bladet, Dagens Nyheder og Berlingske Tidende og der var i sandhed mange at vælge imellem til udstillingen - også fra tiden efter mødet mellem chefredaktørerne og P. Munch; hans bud til redak- tørerne blev nemlig ikke i første omgang fulgt af aviserne. Der skulle et par mindre, diplomatiske kriser til, før Socialdemokraten som den sidste avis i 1936 forbød sine tegnere at fremstille Adolf Hitler. Godt nok erstattede tegnerne Hitler med den mytiske figur, Fru Germania, ${ }^{2}$ for dermed via omveje stadig at kunne satirisere over det nazistiske uvæsen, men alligevel markerede 1936 et skift med hensyn til, hvor meget dagbladene kunne tillade sig.

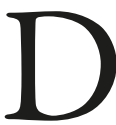
en første krise fandt sted kort efter Hitlers magtovertagelse. Tegningen "Østrigs Nazificering" af Ragnvald Blix var blevet bragt i Berlingske Tidende 30. april 1933 og var dagen efter blevet set af tyske soldater i Berlin, der reagerede kraftigt og besluttede sig for at ransage Berlingske Tidendes stedlige korrespondent, Cai Schaffalitzky de Muckadells hus. Han var paradoksalt nok kendt som en relativt tyskvenlig herre, men udover at oplevelsen var ubehagelig for ham personligt, skabte det frygt i Danmark for, om ransagelsen havde været foretaget på befaling af en officiel, tysk instans. ${ }^{3}$ Heldigvis viste det sig, at det blot var soldaterne selv, der havde taget initiativ til aktionen, men i Danmark skabte det uden tvivl en gryende forståalse for, at satiretegningen er et medie, der dels bevæger sig på tværs af landegrænser med lynets hast, dels kan forstås af andre folk og kulturer meget nemmere og hurtigere end skriftlig satire ville kunne.

En større og mere alvorlig krise fandt sted i løbet af 1935. Det år udkom værket Tegning af Tiden med tegninger af Hans Bendix, heriblandt "Dollfuss in memoriam", hvor Hitler som en moderne Pilatus vasker sine blodige hænder. Tegningen mere end antydede, at Hitler 


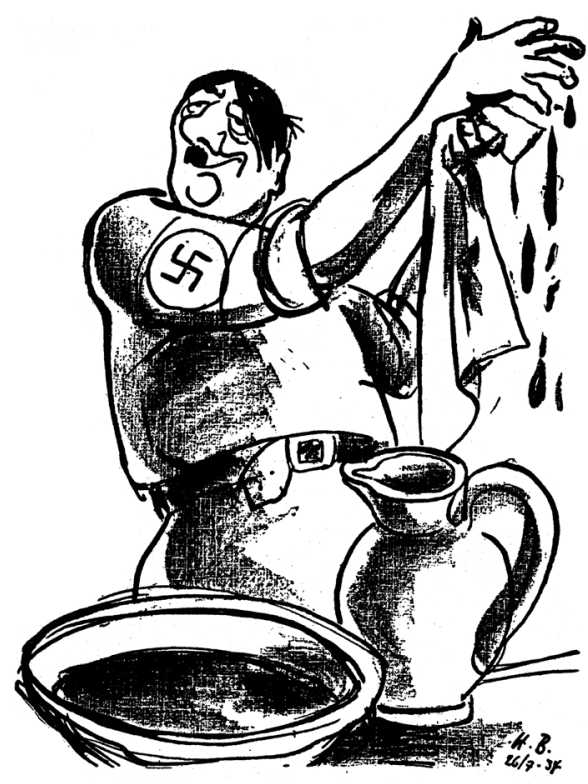

Dollfuss in memoriam

Den moderne Pilatus

Hans Bendix i Tegning af Tiden, 1935

havde været direkte ansvarlig for mordet på den østrigske statsleder, Engelbert Dollfuss, der året forinden var blevet dræbt af østrigske nazister. Bogen kom dog ikke umiddelbart i tyskernes søgelys, men da den socialdemokratiske politiker, humanisten Hartvig Frisch anmeldte bogen og skrev om Bendix, at "Vreden har givet hans Kunst en ny Retning, og skønt Smilet stadig er hans Vaaben, ligger der et skarpladet Projektil i hver Tegning", blev det klart for den tyske presse, hvad der var foregået i det lille land mod nord. Bendix, Frisch og statsminister Stauning blev voldsomt kritiseret, ikke bare i Tyskland, men også i Danmark. På det tidspunkt var det danske fokus på Tyskland i lige så høj grad handelspolitisk, som det var sikkerhedspolitisk. Det var derfor, at Venstres Oluf Krag under finanslovsforhand- lingerne bragte op, at regeringen måtte bringe forholdet til Tyskland i orden efter Frischs i hans øjne uhensigtsmæssigt positive anmeldelse af Bendix' provokerende tegning, således at den danske griseeksport ikke skulle lide voldsomt. Det resulterede i, at Bendix blev kaldt op på statsministerens kontor og fik at vide, at hvis han nogensinde gjorde noget lignende, ville han blive fyret øjeblikkeligt. Man har svært ved at forestille sig, at en statsminister eller anden politiker ville kunne komme med sådanne trusler i dag, og det er blot med til at understrege det meget større tilhørsforhold redaktionerne dengang havde til de respektive partier. ${ }^{4}$

På mange måder var krisen omkring "Dollfuss in memoriam" med til at sætte punktum for tegnernes satiriske stød mod det nazistiske Tyskland, og den kan sagtens have været direkte medvirkende til, at Socialdemokraten forbød sine tegnere at tegne Adolf Hitler. Selvom fru Germania stadig fandt vej til "Dagens Tegning", var det alligevel mest i blade som Kulturkampen, men også Blaksprutten og Svikmøllen, at tegnerne stadig kunne være kritiske over for Hitler, som blandt andet tegningen "Føler De Dem vel truet?" fra 1939 viser.

I det store og hele fortsatte det sådan indtil besættelsen den 9. april 1940, hvor de fleste bladtegnere blev afskediget fra deres respektive blade (nogle var endda nødt til at gå i landflygtighed) og var nødsaget til at finde anden beskæftigelse og tegne til de illegale blade, hvis de ville fortsætte med at kritisere besættelsesmagten ved hiælp af deres tegninger. Der var kun plads til få undtagelser i form af et par enkelte, satiriske bidrag i Blaksprutten, denne gang rettet mod lederen af det danske nazistparti, Fritz Clausen. 
Føler De Dem vel truet?

Herluf Bidstrup i Kultur-

kampen, 1939

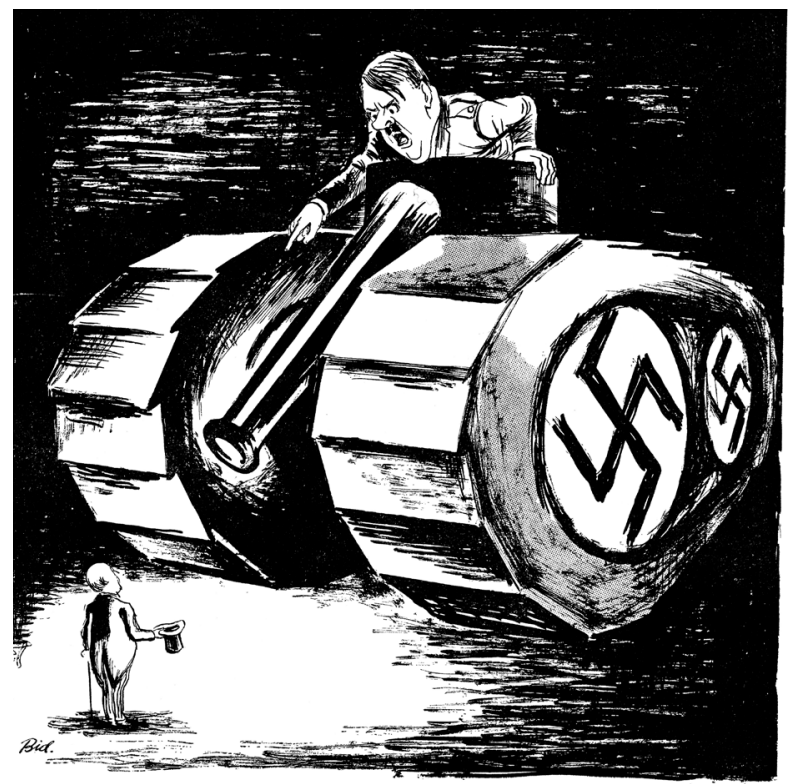

$\mathrm{T}$

ilbage står spørgsmålet om, hvor "bladtegnernes egen avis", Politiken, var i hele denne historie. Og svaret er, som ovenfor antydet, at avisen var fuldstændig fraværende: Politiken var den eneste avis, der allerede fra starten fulgte P. Munchs opfordring til punkt og prikke, i hvert fald hvad angik satiriske tegninger. Men samtidig står det - efter en mindre undersøgelse - helt klart, at denne opfordring slet ikke var rettet mod Politiken. Det var ikke nødvendigt at understrege alvoren over for avisen, for allerede fra Hitler kom til magten den 30. januar 1933 og frem til mødet hos Munch den 2. marts samme år var der absolut ingen tegninger, der afbildede Hitler, og nærmest ingen, der kommenterede det ellers temmelig afgørende, politiske magtskifte i Tyskland. Nuvel, det var jo ikke, fordi der var agurketid i Danmark på dette tidspunkt. Dansk politik var også inde $\mathrm{i}$ en afgørende fase, der kulminerede med Kanslergadeforliget indgået selv samme dag, som Hitler kom til magten. Men det ændrer ikke ved, at alle de andre, danske aviser og deres tegnere - fra Ekstra Bladet til Berlingske Tidende - anså det for nødvendigt at kommentere Hitlers magtovertagelse. Set i lyset af denne opdagelse foretog vi efter udstillingens tilblivelse en udvidet undersøgelse af Politikens "Dagens Tegning" i løbet af 1930'rne, og præcis det samme billede tegnede sig: Af tegninger, der beskæftigede sig med de farlige emner, var der intet nævneværdigt!

Godt nok har der endnu ikke været tid til at gå ned i mindste detalje og gennemgå hver enkelt avis igennem syv år, og konklusionen er derfor baseret på udvalgte stikprøver gennem perioden. Som vores egen samtid har vist os, skal der kun en enkelt tegning til for at skabe diplomatiske vanskeligheder. På den anden side må man sige, at vi i de andre avisers tilfælde var nødt til at fravælge materiale 


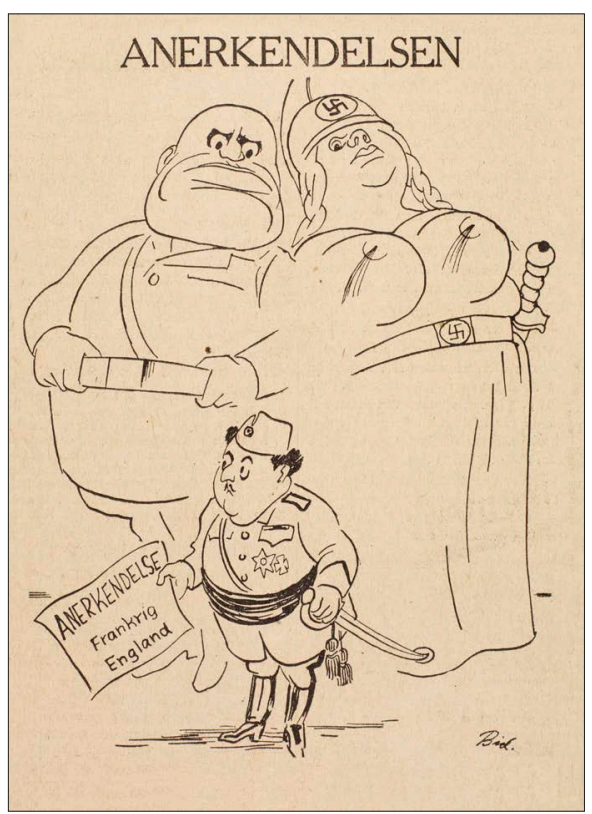

Anerkendelsen

Franco: - Det bliver nok sverere at faa mine kare Hjelpere til at anerkende mig som Spaniens Hersker.

Herluf Bidstrup i Socialdemokraten d. 2. marts 1939

for ikke at overplastre hele Det Kongelige Bibliotek med tegninger! Endelig kan det naturligvis være svært at afgøre, om Politikens mangel på satiriske tegninger omhandlende nazismens uvæsen skyldtes den redaktionelle linje eller tegnernes uvilje mod at tegne emnet.

I starten af 1920'rne begyndte Politiken at bringe "Dagens Tegning" tegnet på skift af de nyansatte tegnere Valdemar Møller (1885-1947) og Carl Jensen (1887-1961). Møller var samtidig avisens faste teatertegner, hvilket lå ganske naturligt for ham, da han også var udøvende skuespiller på Det Kongelige
Teater. Teatertegningen var derfor hans hovedområde, og det fremgår (også) af hans satiriske tegninger, der ofte omhandlede det københavnske kulturliv - ikke mindst teatret. Det kan sagtens have ligget den milde, glade tegner ganske fjernt at komme i clinch med noget så alvorligt som den foruroligende udvikling hos den sydlige nabo. ${ }^{5}$ Noget andet bør dog siges om Carl Jensen. Allerede siden sin ansættelse som ganske ung på Ekstra Bladet $\mathrm{i}$ 1905, havde han befundet sig $\mathrm{i}$ inderkredsen af tegnere, og i 1933 - af alle år - var han medstifter af tegnernes fagforening, Foreningen Danske Bladtegnere. ${ }^{6} \mathrm{Han}$ kendte alle de andre - Bendix, Jensenius, Bidstrup - og det er meget svært at forestille sig, at Jensen ikke har ønsket at give sit personlige bidrag til den satiriske storm, der fulgte i de danske blade efter Hitlers magtovertagelse, og som for flere af aviserne fortsatte i op til fire år. Det ses også ved, at enkelte, meget forsigtige satiretegninger i Politiken om emnet - og i sammenligning med de andre avisers så intetsigende, at vi ikke fandt det relevant at udstille dem - er tegnet af Carl Jensen. ${ }^{7}$ Vi har dog endnu ikke været i stand til at finde nogle korrespondancer eller lignende, der kunne kaste lys over, hvordan Carl Jensen personligt stillede sig over for nazismen og i særdeleshed over for det at satirisere over emnet.

$\mathrm{D}$ et mest sandsynlige er, at det både før og efter mødet hos P. Munch - var Politikens helt klare, redaktionelle linje at afholde sig fuldstændig fra at bringe satiriske tegninger om nazismen, Hitler og tysk politik generelt. At de satiriske tegninger var det mest følsomme medie for Politiken understreges ved, at avisens forsideoverskrifter - som 


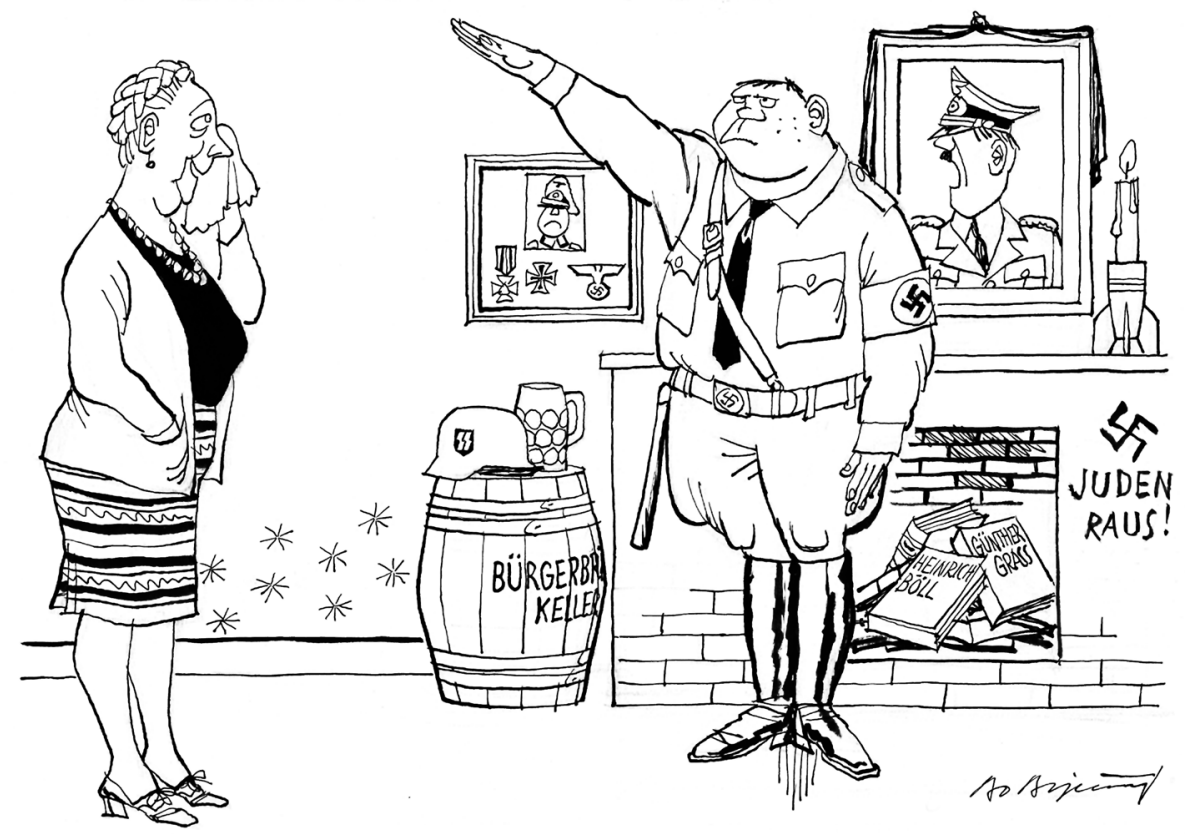

Drømmeland

- Ach, hvor du dog ligner din far, min dreng! Han var også af den sentimentale type.

Både ældre og yngre vesttyskere ligger under for nazi-nostalgien. Bo Bojesen i Politiken d. 29. september 1978

var den anden ting, P. Munch advarede mod - flittigt omhandlede den tyske udvikling i løbet af 1930'rne.

Der er dog ikke noget synderligt overraskende ved, at det netop var Politiken, der afholdt sig fra at bringe satiriske tegninger om nazismen. Avisens helt klare redaktionelle linje var at følge det Radikale Venstre og neutralitetslinjen. Avisens bestyrelsesformand i 1930'rne var tidligere udenrigsminister - og senere statsminister - Erik Scavenius. Og han var efter sigende temmelig involveret $\mathrm{i}$ avisens redaktionelle linje. ${ }^{8}$ Chefredaktørerne Valdemar Koppel og Niels Hasager havde også stærke bånd til det Radikale Venstre Koppel havde endda siddet i borgerrepræ- sentationen for de Radikale i København. Alt i alt ingen overraskelse overhovedet. Alligevel gør to forhold sig gældende, som gør Politikens totale fravær på området interessant. Som tidligere nævnt var Politiken senest i løbet af 1920'rne begyndt at blive betragtet som tegnernes egen avis. Måske var bladet ikke det førende på den satiriske front, især ikke set i lyset af det stærke hold Socialdemokraten kunne mønstre i 1930'rne. Men med både "opfindelsen" af teatertegningen i 1898 og ikke mindst med tilføjelsen af de kunstneriske tegneres legeplads Magasinet i 1922 havde Politiken placeret sig fuldstændig centralt i de samtidige bladtegnernes bevidsthed. Derfor er det interessant, om ikke andet 


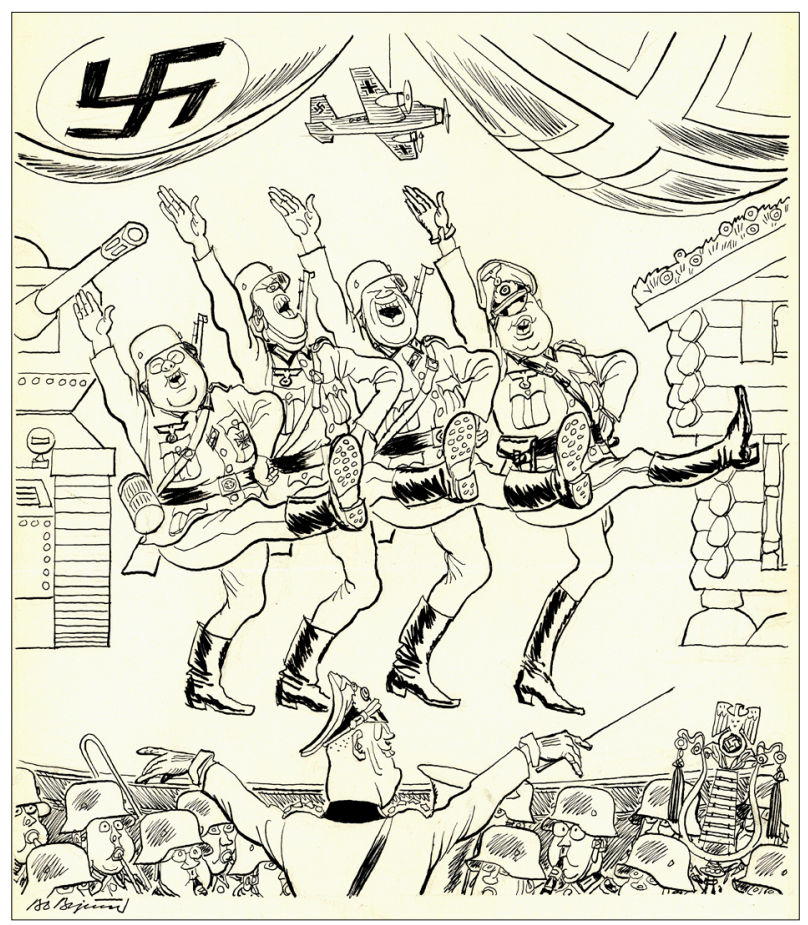

Åh, sikken dejlig krig

- Vielleicht vil der gå

både vinter og vair,

for Norge har glemt,

hvad vi gjorde i går.

Men hvis I kan glemme geschwind, lisom vi gør, sin' wir auch bereit til at tilgi bvis I tor.

Tyske Værnemagtsveteraner holder fest i Berlin den 9. april til minde om overfaldet på Norge.

Bo Bojesen i Politiken

d. 18. februar 1965

ud fra et isoleret, bladtegnerhistorisk synspunkt, at det, da danske bladtegnere for alvor og med en hidtil uset satirisk styrke og enighed kastede sig ind i diskussionen om den politiske udvikling i Tyskland, ikke var denne helt centrale avis, der førte an - den fulgte ikke engang trop.

Mindst lige så interessant er den bredere diskussion om, hvorvidt prædikatet kulturradikalisme bør og skal påsættes (hvis ikke monopoliseres af) Politiken - en diskussion, der konstant dukker op i forskellige afskygninger. ${ }^{9} \mathrm{Nu}$ er problemet med kulturradikalisme imidlertid, at ingen rigtig er enige om, hvad begrebet egentlig dækker over (og den diskussion ønskes heller ikke ført her), men til gengæld er der lidt mere enighed om, at folk som Poul Henningsen, Otto Gelsted og Hans Bendix hører til blandt de prominente bannerførere for kulturradikalismen. P.H. og Bendix arbejdede sammen på Aandebullet - et blad der om noget gjorde, hvad Politiken ikke gjorde: bragte utallige tegninger om nazismen. Sandt er det, at Henningsen var tilknyttet Politiken, men det må samtidig understreges, at dette samarbejde stoppede i 1938, og at det ikke var i Politiken, at P.H.'s kulturradikale ytringer fremkom. ${ }^{10}$ Det er rimeligt at påstå, at hvad angik Politikens holdning til satiriske tegninger i forhold til det gryende diktatur hos den sydlige nabo, der stod realpolitikken altså neutralitetspolitikken - i vejen for Politikens mulighed for at fremstå som en kulturradikal bastion. Først senere, efter krigen, blev Hans Bendix tilknyttet Politiken. På det tidspunkt var Bendix nærmest udelukkende reportage- og teatertegner 
og ville stort set ikke tegne satire mere. En anden stor kritiker af nazismen, den unge sønderjyde Bo Bojesen, blev først ansat på Politiken i 1947, hvor han i overraskende mange år mindede den danske befolkning om, hvilket uvæsen der havde regeret i Tyskland før og under krigen. Det var derfor først, da tingene blev relativt ufarlige, hvis man må være så fræk, at Politiken engagerede tegnere med en erklæret antinazistisk baggrund eller holdning og ændrede sin redaktionelle linje således, at en reel kritik af det tyske terrorregime kunne fremgå i de satiriske tegninger. I 1930'rne, den periode hvor det kunne koste dyrt at udtale sig kritisk over for Nazi-Tyskland og samtidig den periode, hvor de store såkaldte kulturradikalister agiterede for fuldt tryk, var Politiken - kulturradikalismens højborg - for så vidt angik den tegnede satire fuldstændig tavs.

\section{0}

\section{Noter}

1 Hoff omtales af Bo Bojesen i Sofie Lene Bak \& John T. Lauridsen: "Et liv som tegner. Interview med Bo Bojesen”, Ud over alle grenser, Kulturmoder $i$ Bo Bojesens streg, 2000, s. 38.

2 Se tegningen "Anerkendelsen" på side 60. Bemærk i øvrigt, at tegnerne tolkede P. Munchs bud fra marts 1933, der ellers bød ikke at tegne udenlandske statsledere, som kun at gælde Hitler. Mussolini og Franco havde man ingen angst for.

3 Rasmus Kreth: Pilestrede under pres. De Berlingske Blade 1933-1945, 1998, s. 7379.

4 Hele historien om "Dollfuss in memoriam” fortælles af Jesper Düring Jørgensen

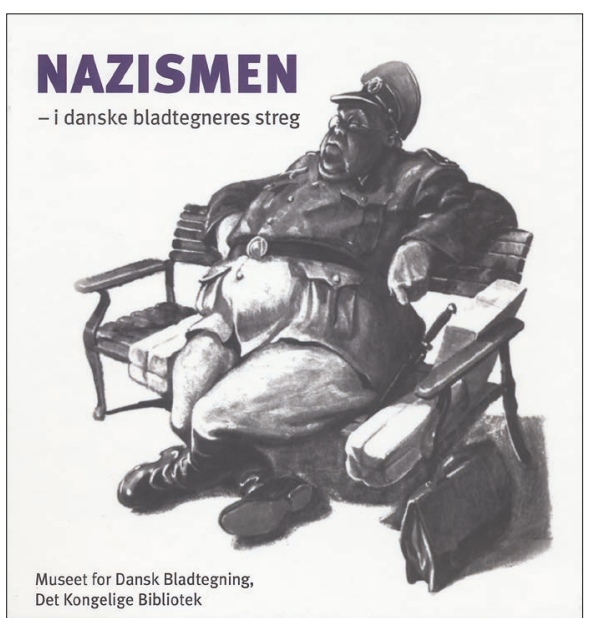

Nazismen - i danske bladtegneres streg, red. af Claus Seidel og Hannibal Munk, 2012, kan erhverves i Diamantboghandlen eller via Det Kongelige Biblioteks hjemmeside <webbutik.kb.dk>

Bogen rummer alle tegningerne fra udstillingen.

i kronikken "Antinazisten Hans Bendix", Politiken, 19.1.1991.

5 Søren Vinterberg: Levende streger. Politikens tegnere og tegneserier i 125 ar, 2009, s. 184.

6 Hans Edvard Nørregaard-Nielsen: Avisens Haindskrift. Dansk Bladtegning gennem et halvt arrhundrede, 1983, s. 12.

7 Her kan nævnes "Dagens Tegning" i Politiken 8.4.1933 som eneste reelle mulighed.

8 Bjørn Bredal: Politiken mod Politiken. Idékampe 1884-2009, 2009, s. 250-252.

9 Se f.eks. Rune Lykkeberg: "Vi er kulturradikale..., Politiken 7.12.2013; Christoffer Emil Bruun: "På besøg i Frederik Stjernfelts glashus”, Politiken 14.8.2013.

10 Bredal 2009, s. 248-250. 